\title{
Sustainable Food Production for a Complete Diet
}

\author{
E. Glenn and C. Clement \\ Environmental Research Laboratory, University of Arizona, Tucson, Ariz.
}

\author{
P. Brannon \\ Department of Food Science and Nutrition, University of Arizona, Tucson, Ariz.
}

\author{
L. Leigh \\ Space Biospheres Venture, Oracle, Ariz.
}

\section{INTRODUCTION}

Home gardens provide relatively little supplemental food or in come for most practitioners in the United States (Utzinger and Connolly, 1978; Wishnetsky and Cash, 1976). but they can be important sources of supplemental nutrition and income for people in developing countries (Gershon and Yen-Ching. 1984; Mullane, 1981; O’Brien-Place, 1987; Yoon, 1983).

Family gardens can provide a form of food security if they are keyed to specific nutritional needs (Gershon and Yen-Ching. 1984; Popkin et al.. 1980). The extent to which it is practical to produce a complete diet in a garden is unknown. Duhon and Gebhard (1985) are representative of an organic fanning movement that advocates complete food independence through sustainable family gardens. They estimate that a complete diet can be produced on as little as $100 \mathrm{~m}^{2}$ of land with few external inputs. NASA estimates of the space to produce a complete diet are as low as $25 \mathrm{~m}^{2}$ (Hoff et al., 1982). To our knowledge, these estimates have not been verified experimentally.

We have helped to develop the food production system for Biosphere II. a closed, I-ha ecosystem in which eight people will grow their own food using natural desert soil and sustainable meth ods. As a pretest of the system, we have attempted to produce all of the elements of a complete diet. made up of a diverse collection of food crops, on a minimal area in Tucson, Ariz. The experiment tested the feasibility of producing all or most of a family's nutritional needs on a small piece of soil using manual labor and no outside inputs. The experiment was conducted in a greenhouse to simulate the continuous cropping conditions that exist in tropical locations (Sanchez and Benites. 1987) as well as the conditions expected in Biosphere II and possible future space habitations (Hoff et al., 1982).

\section{MATERIALS AND METHODS}

Nutrient analyses of complete diets. A series of balanced diets based on the major food groups was developed by Brannon and Norem, using USDA Dietary Guidelines (Pennington and Church, 1985). Nutrient content of foods was based on cooked values where applicable (fresh fruits and vegetables were assumed to be used raw).

The diet chosen for testing was a high-grain vegetarian diet. supplemented with one cup per day of goat milk. The diet met or ex ceeded the RDA for adult males and females aged 23 to 50 for all nutrients except vitamin $B_{12}$. The calcium content of the diet would have to be increased for children, pregnant women, and lactating women. and the iron and vitamin content would have to be increased for people older than 50 .

Nutrient contents were determined for classes of like foods to allow for easy substitution of foods within the groups. The diet has excess content of many nutrients including calcium, iron, vitamin
A, thiamin, folic acid, vitamin $\mathrm{C}$, and vitamin B6. Hence, intakes skewed towards a particular food within a group were expected to have a minimal impact those nutrients.

Growing the elements of the diet in a sustainable garden plot. Except for rice, potatoes. and dark-green leafy vegetables, the ele ments of the diet were grown in a $40-\mathrm{m}^{3}$ lysimeter plot (1-m depth) in a controlled environment greenhouse for 420 days, during which time all the crops in the diet were grown in proper rotation (the growing experiment has been continued into the second round of crops). The soil was a desert sandy loam, containing $72.3 \%$ sand, $19.9 \%$ silt, and $6.9 \%$ clay. It was initially amended with $2.5 \%(\mathrm{v} / \mathrm{v})$ peat evenly distributed throughout the soil profile. During the ex periment, a steady, slow stream of air was blown through the soil, to test the bed as a method for removing toxicant gasses (i.e., as a soil bed reactor), and the purpose of the pear was to improve air flow rather than to affect agronomic performance. Other experiments showed that the passage of air through the soil had no measurable effect on crop performance (Olsen et al., unpublished data).

The cultivation practices were standard "organic gardening" methods based on rotations of heavy feeding crops with light feed crops followed by alfalfa 10 restore the soil (Duhon and Gebhard. 1985; Olkowski et al., 1979). Open-field agricultural yields were used to determine the size of the plots devoted 10 each crop for the first year of operation. Aphids were controlled by releasing ladybird beetles into greenhouse and by washing plants. Infected plant material was composted or destroyed. No pesticides or herbicides were used in the greenhouse environment during the course of the experiment of the previous year. No chemical fertilizers were used.

Prior to growing the first rotation of crops, $13.5 \mathrm{~kg} \cdot \mathrm{m}^{-2}$ of com posted sheep manure was mixed into the top $25 \mathrm{~cm}$ of the soil profile. Thereafter, the only additions to the soil were: 1) crop residues grown on the soil, and 2) an amount of chicken manure calculated to contain as much nitrogen as would be in the feces and urine of a person who ate the food from the garden. It was assumed initially that the garden would provide $20 \%$ of a complete diet and the allot ment of chicken manure was set at $58 \mathrm{~kg} \cdot \mathrm{year}^{-1}$ based on $20 \%$ of the nitrogen output of a person and $1.1 \%$ nitrogen content in chicken manure (Hoff et al., 1982; Olkowski et al., 1979). Nine kilograms of chicken manure was added directly to the soil in the form of "manure tea" applied to the sweetpotato plot and the remainder was composted with the crop residues and alfalfa cuttings as they became available. Chicken manure and dried plant material was mixed in a 1:1 (w/w) ratio and aerobically composted in a drum.

Rice was grown paddy-style along with azolla in small watertight boxes. The soil mix was the same as the main bed. Two crops per year are grown in the boxes, with azolla turned into the soil between crops as the only outside input. Potatoes were grown in 0.6$\mathrm{m}$ boxes using the same soil as the main bed, but supplemented with $20 \mathrm{~kg} \cdot \mathrm{m}^{-2}$ of compost between crops (two per year). Vegetables were also grown in a separate box that received extra compost (prepared from common allotment given above). 
Records were kept of all above-ground biomass produced during the experiment, and of all input-s of manure, compost, silage (sweet potato vines). or straw. The amount of water applied was measured by using a flow meter attached to the hose. No leachate water was produced during the first 420 days of the experiment. Manpower requirements were estimated by the time sheets filled out by the gardeners working on the experiment. They did not break down their time into individual tasks, but the average nonsupervisory labor was $\approx 1 \mathrm{hr} /$ day over the course of the experiment.

Analytical methods. Soil samples were taken for analyses of organic matter, Olsen's $\mathrm{P}$, nitrate- $\mathrm{N}, \mathrm{EC}, \mathrm{K}$ and $\mathrm{pH}$ at 6-month intervals. The initial soil analysis was based on a pooled sample of 10 subsamples from within the plot- taken before planting. Thereafter, the plot was divided into eight zones and each zone was sampled at three to five locations. The zones were analyzed separately. Soil samples were ovendried after collection. and analyzed by the Dept. of Soil and Water Science. Univ. of Arizona- Tucson. The starting compost (composted sheep manure) and representative samples of compost made during the experiment also were analyzed.

The caloric content of foods was determined using values in Pennington and Church (1985). The caloric content of alfalfa and crop residues were determined from values in National Academy of Sciences (1971).

Horizontal radiation was measured outdoors by the Dept. of Atmospheric Physics and greenhouse values were calculated from those data and the measured transmissivity of the greenhouse roof $(80 \%)$.

Soil respiration was estimated from short-term data collected by Frye (unpublished data), which showed a relationship between soil respiration and percentage compost for this soil $\left(\mathrm{g} \mathrm{CO}_{2} / \mathrm{m}^{2}\right.$ per day $=7.3 .5+0.557 *$ (\% compost $), r=0.827)$. The nitrogen fixation by legumes was estimated from yields and literature values for $\mathrm{N}$ fixation rates of alfalfa and dry berms as functions of yield (Hamdi, 1982).

\section{RESULTS}

The diet was divided into eight major food groups plus milk (Table 1). and was based on a list of 40 crops (Table 2) (only the major crops were grown in the horticulture experiment). The nutritional analyses showed that for adult males and females, foods could be substituted freely within the food groups. The caloric con tent of the diet was $\approx 2200 \mathrm{kcal} / \mathrm{day}$. which is considered adequate for active males and females. The diet was vegetarian, with the exception of milk, which provided higher levels of calcium and riboflavin than could be obtained from plant sources alone. The supply of these two nutrient-s also was augmented by the category of dark-green leafy vegetables. The percentages of calories supplied by protein, carbohydrate, and fat was similar to U.S. Dietary Guidelines. but the amount of oil. $11 \mathrm{~g} \cdot \mathrm{day}^{-1}$. was much lower than the average U.S. diet.

Figure 1 shows the layout of crops at the initial planting in June 1988. and subsequent winter and spring rotations. The crops were not laid out in replicated blocks; rather, the planting scheme was de signed to simulate an actual garden layout and to achieve the maximum output of food from the available space. Tall crops were placed east of shorter crops to maximize sunlight interception. A tall vine crop of snake beans were grown on strings along the east edge of the bed in one trial. This crop intercepted light that would not be available on the horizontal surface of the plot- and. for that reason. the yield data from that crop are not included here. Several cultivars of each crop were tried. whenever possible (-1-able 2). and no hybrid seeds were used. One of the goals was to produce all the seed or propagules necessary for replanting the crops.

Alfalfa was grown to the maximum extent possible in the garden. It was planted in rotation with other crops. in the walkway area that gave access to the plots. and as an intercrop with the food crops. It was used as a feedstock for the cornposter. and simulated the production of forage for a goat to provide milk.

\section{Decenter 21,88 June 21, July 21, a) dug 21, 1988 \\ January 21,1989}

711 ay 21, 1989
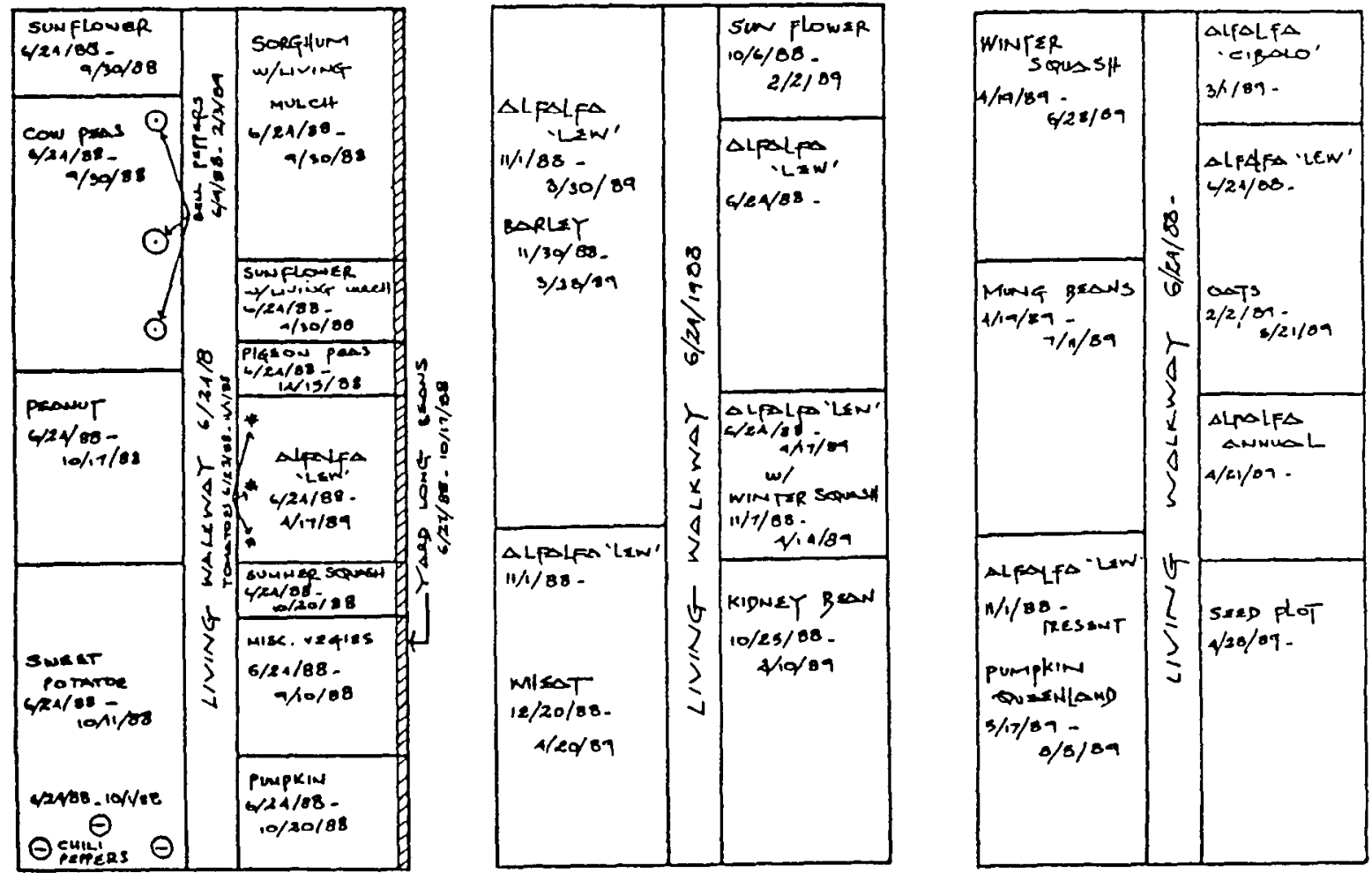

Fig. 1. Layout of crops in the sustainable garden at three points in the rotation plan. 
Table 1. Nutritional analysis of high-grain diet with one cup of goat milk included (based on average food consumption). The diet exceeds RDAs for males and females for all minerals and vitamins, except $\mathrm{B}_{12}$, which is only supplied at $\% 5$ of RDA.

\begin{tabular}{|c|c|c|c|c|c|c|c|}
\hline \multirow[b]{2}{*}{ Item } & \multicolumn{2}{|c|}{ Weight (o/day) } & \multirow[b]{2}{*}{ kcal } & \multirow[b]{2}{*}{ Protein (g) } & \multirow[b]{2}{*}{$\mathrm{CHO}(\mathrm{g})$} & \multirow[b]{2}{*}{ Fat (g) } & \multirow[b]{2}{*}{ Calcium (g) } \\
\hline & Raw & Cooked & & & & & \\
\hline Grain & 251 & & 900 & 29.2 & 182 & 9 & 164 \\
\hline $\begin{array}{l}\text { Starchy vegetables } \\
\text { Legumes }\end{array}$ & 150 & & 102 & 2.2 & 24 & 0 & 25 \\
\hline High fat & 72 & 107 & 372 & 20.4 & 16 & 28 & 101 \\
\hline Low fat & 162 & 445 & 549 & 36.4 & 100 & 2 & 185 \\
\hline Other & 150 & & 53 & 1.8 & 12 & 1 & 50 \\
\hline $\begin{array}{l}\text { Dark-green leafy } \\
\text { vegetables }\end{array}$ & 170 & & 41 & 3.6 & 8 & 0 & 217 \\
\hline Goat milk & 244 & & 168 & 8.7 & 11 & 10 & 326 \\
\hline Oil & 11 & & 97 & trace & 0 & 11 & 0 \\
\hline $\begin{array}{l}\text { Total } \\
\text { Percent kcal } \\
\text { U.S. dietary guidelines }\end{array}$ & 1210 & & 2282 & $\begin{array}{l}102.3 \\
17 \\
12\end{array}$ & $\begin{array}{r}353 \\
57 \\
58\end{array}$ & $\begin{array}{l}61 \\
26 \\
30\end{array}$ & 1068 \\
\hline
\end{tabular}

Table 2. List of primary food crops grown in the sustainable garden plot. arranged by food group. Within a food group, foods can be substituted for each other freely and the diet will still beet RDAs and dietary guidelines. Recommended cultivars are listed for the major crops.

\section{Grains}

Barley (Gusto, Barcott). Brown rice (M201, L202 S101), Oats (Pennuda, Pennlo, Florida 501). Sorghum (BTK-623, Hegari, Wheatland),

Wheat (whole) (Yecora Anza), Durum wheat (Yabaros, Alduras)

Starchy vegetables

Potatoes with skin (Atlantic), Pumpkin (none recommended), Sweetpotatoes (Jewel), Winter squash (none recommended)

High fat legumes and oilseeds

Peanuts (Burpee Spanish), Sunflower seeds (none recommended)

Low fat legumes

Cowpeas (California, Black-eye 5), Dried beans (Kidney, Pinto), Pigeon peas (none recommended)

Other vegetables and fruit

Bananas, Bean, Beets, Bell pepper. Broccoli, Cabbage, Cantaloupe, Carrot, Chinese cabbage, Cucumber. Eggplant. Guava, Kumquat, Grange, Papaya, Pea (edible pod), Radish, Strawberry, Tomato

Dark green leafy vegetables

Beet greens, Collards Mustard greens, Parsley, Spinach, Swiss chard, Turnip greens

Animal products

Goat milk

Animal feeds

Alfalfa (Lew, Cibola). Excess crops and residues

Table 3 gives the planting areas, yields, and caloric content of the food from the garden. Although the garden was only $40 \mathrm{~m}^{2}$ plus an additional $4 \mathrm{~m}^{2}$ for rice, potatoes, and vegetables, the area planted to food crops over the experiment was $74.9 \mathrm{~m}^{2}$, reflecting multi ple crops on the same soil. A total of $108,829 \mathrm{kcal}$ were produced over 420 days. This is $12 \%$ of the diet requirement (excluding milk). Due to deviations of actual yields from projected yields, the percentage of foods from the major food groups did not exactly match the target diet (Table 1). The achieved diet was 3\% higher in grains. $19 \%$ lower in legumes. and $75 \%$ higher in starchy vegeta bles than the target diet. but the percentages of calories in protein, fats, and carbohydrates were similar to target figures (data not shown).

The majority of crops exceeded the target yields, but problem crops were sunflower, pigeon pea, and winter squash. These all yielded less than half of the open-field yields. Greater space-use ef ficiency could be achieved in subsequent crops by substituting good performing crops for these three. Direct-seeded sorghum performed poorly, but other grain yields were high. Oats performed exceptionally well, yielding high in grain as well as straw for com posting.

Yields of alfalfa and other non-food biomass are presented in Table 4. Alfalfa produced nearly as many kcal as the edible food.
More than half of the alfalfa came from plants grown as intercrops within the food plots. These plants were cut short when the food crops were grown, and were allowed to regrow after the food was harvested. The next largest category of alfalfa came from the "liv ing walkway", an area that was inconvenient to plant with foods but supported good alfalfa production. Alfalfa grown in rotation with food crops was the smallest source. More than $23 \mathrm{~kg}$ of dry alfalfa was harvested, an amount that was more than sufficient to support the needed level of goat milk production (assuming $2 \mathrm{~kg} \cdot \mathrm{day}^{-1}$ of fodder requirement of a goat producing 4 liters of milk per day).

The straw from the crops yielded an addition $251.615 \mathrm{kcal}$. $\approx 25 \%$ of which came from legume crops and $75 \%$ from nonlegumes. Counting alfalfa, legumes accounted for $47 \%$ of the total kcal of crop production (edible and nonedible).

Soil analyses (Table 5) showed a decline in available phosphate over the experiment; however. the final level was still considered adequate for crop production. Organic matter within the root zone remained high, reflecting the return of compost and crop residues, and nitrate-N levels were sufficient at the end of the first 420 to re plant the plots. The soil remained alkaline throughout the first crop cycle and salinity (EC) in the root zone did not increase despite the fact that no leachate was produced from bed.

An approximation of the amounts of nitrogen and carbon cycled 
Table 3. Yield of major crops from sustainable garden. The crops were either direct-seeded (D) or transplanted $(\mathrm{T})$.

\begin{tabular}{|c|c|c|c|c|c|}
\hline Crop & Yield $\left(\mathrm{g} / \mathrm{m}^{2}\right)$ & Target $(\%)$ & Area $\left(m^{2}\right)$ & Amount (g) & $\mathrm{kcal}$ \\
\hline \multicolumn{6}{|c|}{ Grains } \\
\hline \multicolumn{6}{|l|}{ Sorghum } \\
\hline$D$ & 108 & 24 & 2.5 & 270 & 896 \\
\hline$T$ & 652 & 144 & 2.5 & 1.630 & 5.412 \\
\hline \multicolumn{6}{|l|}{ Wheat } \\
\hline$D$ & 499 & 154 & 3.1 & 1.532 & 5,102 \\
\hline$T$ & 407 & 125 & 3.6 & 1.465 & 4.878 \\
\hline \multicolumn{6}{|l|}{ Oats } \\
\hline$D$ & 525 & 290 & 2.8 & 1.470 & 5.733 \\
\hline$T$ & 564 & 311 & 2.8 & 1,579 & 6,158 \\
\hline \multicolumn{6}{|l|}{ Barley } \\
\hline D & 311 & 145 & 5.3 & 1,648 & 5.768 \\
\hline $\mathrm{T}$ & 265 & 123 & 5.3 & 1.405 & 4.928 \\
\hline Rice (two crops) & 1,248 & 100 & 1.9 & 2,308 & 8,309 \\
\hline TOTAL & & & 31.7 & 13,307 & 47,184 \\
\hline \multicolumn{6}{|c|}{ Legumes } \\
\hline \multicolumn{6}{|l|}{ Cowpea } \\
\hline$D$ & 428 & 428 & 8.2 & 3,497 & 11.995 \\
\hline \multicolumn{6}{|l|}{ Dry bean } \\
\hline $\mathrm{D}$ & 209 & 86 & 6.1 & 1.275 & 4,335 \\
\hline \multicolumn{6}{|l|}{ Mung bean } \\
\hline D & 304 & 125 & 5.6 & 1.702 & 5.650 \\
\hline Pigcon pea & 136 & 147 & 1.7 & 227 & 5.561 \\
\hline TOTAL & & & 21.6 & 6,701 & 27.631 \\
\hline \multicolumn{6}{|c|}{ Starchy vegetables } \\
\hline Sweetpotato & & & & & \\
\hline$T$ & 2,379 & 198 & 6.1 & 5,701 & 5.929 \\
\hline \multicolumn{6}{|l|}{ Squash } \\
\hline$T$ & 1.239 & 38 & 2.2 & 2,750 & 1,072 \\
\hline Potato (two crops) & 27,028 & 480 & 0.4 & 5,000 & 10.900 \\
\hline \multirow[t]{2}{*}{ TOTAL } & & & 8.7 & 13.451 & 17.901 \\
\hline & & Oilseeds & & & \\
\hline \multicolumn{6}{|l|}{ Sunflower } \\
\hline D.T & 123 & 39 & 5.6 & 775 & 4,418 \\
\hline \multicolumn{6}{|l|}{ Peanut } \\
\hline D & 361 & 130 & 3.9 & 1.408 & 7.969 \\
\hline TOTAL & & & 9.5 & 2.183 & 12,387 \\
\hline \multicolumn{6}{|l|}{ Leafy greens } \\
\hline$T$ & & & 3.4 & 13.803 & 3.726 \\
\hline GRAND TOTAL & & & 74.9 & 47,262 & 108,829 \\
\hline
\end{tabular}

in the plot are given in Table 6. These calculations show that the legumes fixed nearly as much nitrogen as was lost from the system. The main sources of inefficiency in the recycling program were: 1) crop residue, which was discarded rather than recycled due to infes tation with insects; and 2) losses of organic matter and nitrogen dur ing the composting process. The carbon content of the soil would (theoretically) be drawn down from the initial high level due to soil respiration.

The overall photosynthetic conversion efficiency was $0.667 \%$. but the conversion into edible food was only $0.157 \%$ (Table 7). A total of $45.5 \mathrm{~m}^{3}$ of water was applied (equal to $0.99 \mathrm{~m} \cdot \mathrm{year}^{-1}$ ).

\section{DISCUSSION}

The amount of land and labor required to produce a complete diet is higher than other estimates. Duhon and Gebhard (1985). using essentially the same techniques we used, estimated that a complete diet would require $100 \mathrm{~m}^{2}$ of land and 1 to $2 \mathrm{hr}$ of work per day; Hoff et al. (1982) had even lower estimates for hydroponic methods. However. those studies did not actually grow all the crops; rather. they were projections. We have found that, even under favorable greenhouse conditions, gardening for complete nutrition requires $250 \mathrm{~m}^{2}$ of land under continuous cropping (this could be achieved by substituting higher-yielding crops for the unsuccessful ones in the present experiment).

Estimates of the labor needed to operate vegetable gardens vary among studies, from $5.4 \mathrm{~min} \cdot \mathrm{m}^{-2} \cdot \mathrm{year}^{-1}$ for mechanized semi-com mercial gardens in Florida (average size of $2360 \mathrm{~m}^{2}$ ) (Gladwin and Butler, 1982) to $22 \mathrm{~min} \cdot \mathrm{m}^{-2} \cdot \mathrm{year}^{-1}$ for a $15-\mathrm{m}^{2}$ home garden in Ohio (Utzinger and Connolly, 1978). The present sustainable garden experiment required much more human input: $\approx 550$ $\min \cdot \mathrm{m}^{-2} \cdot \mathrm{year}^{-1}$. Detailed records were not kept of all tasks performed. The high labor requirement was partially due to the continuous cropping system and the labor-intensive tasks of hand water ing. transplanting, cutting alfalfa, composting residues, threshing and cleaning seeds and grains, and growing-out plants for seed pro duction. One of the goals for future research is to better define the 
Table. 4. Production of nonedible biomass in the sustainable garden. Alfalfa was grown in three ways: as a cover crop in rotation with food crops; in the walkway area as a permanent cover; and as a living mulch (intercrop) between the rows of the food crops. The alfalfa was cut at 1- to 2-month intervals, dried, and weighed

\begin{tabular}{lcrc}
\hline \hline Biomass & $\begin{array}{c}\text { Growth rate } \\
\left(\mathrm{g} \cdot \mathrm{m}^{-2} \cdot \text { day }^{-1}\right)\end{array}$ & $\begin{array}{c}\text { Amount } \\
(\mathrm{g} \text { dry wl })\end{array}$ & $\mathrm{kcal}^{\mathbf{z}}$ \\
\hline Alfalfa & & & \\
$\quad$ Rotated w/ food crops & 3.2 & 4,332 & \\
$\quad$ Planted in walkway & 4.6 & 6,237 & \\
Interctopped w/ foods & 3.9 & 12,774 & \\
TOTAL & & 23,343 & 100,608 \\
Straw from crops & & & \\
$\quad$ Non-legume & & 62,700 & 185,153 \\
Legume & & 20,900 & 66,462 \\
TOTAL & & 83,600 & 251.615 \\
GRAND TOTAL & & 107,034 & 352.223 \\
\hline
\end{tabular}

${ }^{\mathrm{z}}$ Assuming $4310 \mathrm{kcal} / \mathrm{kg}$ for sun-cured alfalfa, $2953 \mathrm{kcal} / \mathrm{kg}$ for non-legume (wheat) straw, and $3180 \mathrm{kcal} / \mathrm{kg}$ for legume (bean, cowpea, peanut) straws (Atla.s of Nutritional Content of United States and Canadian Feeds).

Table 5. Soil analysis of sustainable garden at intervals after planting. Each number represents a composite sample of 24 individual soil samples taken throughout the plot in the root zone $(\approx 15 \mathrm{~cm}$ deep).

\begin{tabular}{lccc}
\hline Variable & Initial & 6 months & 12 months \\
\hdashline Organic C & 1.80 & 1.53 & 1.60 \\
Nitrate-N & 15.80 & 9.50 & 9.10 \\
Olsen's P & 142.00 & 121.00 & 69.00 \\
EC & 1300.00 & 1520.00 & 870.00 \\
pH & 8.4 & 8.0 & 8.2
\end{tabular}

Table 6. Estimated mass balance with respect to nitrogen and carbon of the sustainable garden over the first 420 days.

\begin{tabular}{|c|c|c|}
\hline Mass & $N(\mathrm{~kg})$ & $C(\mathrm{~kg})$ \\
\hline $\begin{array}{l}\text { Added initially } \\
\text { Fixed from air }\end{array}$ & 9.5 & 143 \\
\hline $\begin{array}{l}\text { Non-legume } \\
\text { Legume crops (straw + seeds } \\
\text { Alfalfa } \\
\text { TOTAL }\end{array}$ & $\begin{array}{l}0 \\
0.6 \\
0.8 \\
1.4\end{array}$ & $\begin{array}{r}37 \\
10 \\
10 \\
82^{2}\end{array}$ \\
\hline $\begin{array}{l}\text { Recycled } \\
\text { Manure } \\
\text { Compost } \\
\text { Suaw } \\
\text { Silage } \\
\text { TOTAL }\end{array}$ & $\begin{array}{l}0.1 \\
0.9 \\
0.1 \\
0.1 \\
1.2\end{array}$ & $\begin{array}{r}1 \\
13 \\
5 \\
2 \\
21\end{array}$ \\
\hline $\begin{array}{l}\text { Remove from soil } \\
\text { All crops } \\
\text { Minus amount fixed } \\
\text { Net } \\
\text { Soil respiration (initial value) }\end{array}$ & $\begin{array}{l}2.9 \\
1.4 \\
1.5\end{array}$ & $\begin{array}{r}0 \\
97\end{array}$ \\
\hline $\begin{array}{l}\text { Losses due to inefficiencies } \\
\text { Nonrenumed residues } \\
\text { Compost loss }\end{array}$ & $\begin{array}{l}0.4 \\
0.3\end{array}$ & $\begin{array}{l}13 \\
23\end{array}$ \\
\hline Net to soil & -0.3 & -51 \\
\hline
\end{tabular}

Includes roots.

HortScience, Vol. 25(12), DeCEMBER 1990
Table 7. Photosynthetic conversion efficiency in the sustainable garden, based on total radiation measured in $\mathrm{kcal} / \mathrm{m}^{2}$.

\begin{tabular}{ll}
\hline \hline Total radiation & $6.89 \times 107$ \\
Food (kcal) & $1.08 \times 105$ \\
Non-food (kcal) & $3.52 \times 105$
\end{tabular}

$\begin{array}{ll}\text { Photosynthetic efficiency (\%) } & \\ \text { Food } & 0.157 \\ \text { All above-ground biomass } & 0.667\end{array}$

labor requirements, by task. and to substitute efficient cultivation and postharvest methods for laborious hand methods.

Considerable labor savings could be achieved by mechanizing the operations and using chemical fertilizer and pesticides; howev er, the garden would no longer be independent of outside inputs. Considerable space saving could be achieved by growing only the highest-yielding crops (Hoff et al., 1982). but the diet would lose palatability. Further, depending on fewer crops would increase the risk of failure. The present cropping plan produced sufficient balanced kcal of food, despite the failure of some of the major crops, since other crops yielded above the projections.

Given a source of water delivery to the farm, the sustainable garden does appear to be feasible. The water usage tended to be high when expressed on a unit-area basis, but water use efficiency was actually quite high. The fact that no leachate water was produced from the bottom of the bed shows that irrigation efficiency was high, and the use of transplants and tight plant spacings minimized the amount of bare surface from which water could evaporate.

Fodder and grains are not normal garden products but they were among the most successful types of crops in the present case. Based on present alfalfa growth rates ( 3 to $5 \mathrm{~g} \cdot \mathrm{m}^{-2} \cdot \mathrm{day}^{-1}$ ). a goat could be raised on a $500-\mathrm{m}^{2}$ plot devoted entirely to fodder product ion, or on a $1270-\mathrm{m}^{2}$ plot producing complete nutrition (the size required for a family of four). Adding goat milk to a vegetarian diet enhances its nutritional value by providing key nutrients (calcium, riboflavin, and high-quality proteins). The garden also was highly productive of oats, wheat. barley, and sorghum, which are desirable supplements to poor-quality diets, and was a good source of calories in the form of potatoes and sweetpotatoes, protein in the form of cowpeas and beans, and vitamins in the form of dark-green leafy vegetables. Only the oil crops were disappointing; this may have been partly due to reduced light in the greenhouse environment.

Although organic gardens such as this one are called "sustainable" (Duhon and Gebhard 1985). the soil analyses and mass balance estimates suggest that eventually the soil may become deficient in available P. Organic matter also would decline, at least initially, but it is expected that eventually a balance would be reached as soil respiration rates declined. It appears to be easier to maintain soil nitrogen levels, through legume crops, than to maintain high carbon levels, but this hypothesis needs to tested by further operation of the experiment.

The garden started with a relatively high initial compost level, but Olsen et al. (unpublished data) found that the same soil, started out with as little as $2.5 \mathrm{~kg} \cdot \mathrm{m}^{-2}$ compost, could be continuously cropped with only composted crop residues returned to the soil over six crop rotations in which legumes were rotated with grains and vegetables. Similarly. Sanchez and Benites (1987) found that con tinuously cropped acid soil in Peru supported seven crops of rice ro tated with cowpeas in untilled soil in which crop residues were re turned. compared to a single crop of each when crop resides were removed and soils were tilled. After the seventh crop yields and soil organic matter began to decline, but could be restored by grow ing a 1 -year green manure legume to plow under.

Given the small size of the sustainable food garden and the success of growing alfalfa. restoring the soil should it become deficient does not appear to be major constraint. The sustainable food garden does appear to have potential as a means to upgrade a poor-quality diet and provide food security.

The present results need to be translated into practical outdoor gardening systems for specific locations. 


\section{Literature Cited}

Blaylock. J.R. and A.E. Gallo. 1983. Modeling the decision to produce vegetables at home. Amer. J. Agr. Econ Nov. p. 722-729.

Duhon D. and C. Gebhard. 1985. One circle-how to grow a complete diet in less than 1,000 square feet. Ecology Action, Willits. Calif.

Gladwin, C.H. and J. Butler. 1982. Gardening: a survival strategy for the small, part-time Florida farm. Proc. Fla State Hort. Soc. 95:264-268.

Hamdi. Y.A. 1982 Application of nitrogen-fixing systems in soil improvement and management FAO, Rome. Soils Bul. 49.

Hoff, J.E.. J.M. Howe, and C.A. Mitchell. 1982. Nutritional and cultural aspects of plant species selection for a regenerative life support system. NASA Ames Research Center, Moffett Field. Calif.

Mullane, L. 1981. A new food supply at the doorstep. Agenda Mar. 1981. p. $2-5$

National Academy of Sciences. 1971. Atlas of nutritional data on United Slates and Canadian feeds. National Academy Press. Washington, D.C.
O’Brien-Place. P.M. 1987. Evaluating home garden projects. AID, Washington D.C.

Olkowski. H.. B. Olkowski, T. Javits. et al. 1979. The integral urban house. Sierra Club Books. San Francisco.

Pennington, J.A. and H.N. Church. 1985. Food values of portions commonly used. $141 \mathrm{~h}$ ed. Harper \& Row, New York.

Popkin. B.M.. F.S. Solon. T. Fernandez. and M.C. Latham. 1980. Benefitcost analysis in the nutrition area: A project in the Philippines. Soc. Sci. Med. 14:207-216.

Sanchez, P.A. and J.R. Benites. 1987. Low-input cropping for acid soils of the humid tropics. Science 238: 1521-1527.

Utzinger. J.D. and H.E. Connolly. 1978. Economic value of a home vegetable garden. HortScience 13: 148-149.

Wishnetsky. T. and J.N. Cash. 1976. Home gardening and canning vs. buying canned good. Michigan Slate Univ. Coop. Ext. Serv. Bul. E936.

Yoon, S.Y. 1983. Women's garden groups in Casamance. Senegal. Assignment Children 63/64:133-153. 